\title{
Ecotoxicological effects of cadmium on the germination and initial development of Schinus terebinthifolius
}

\section{Efeitos ecotoxicológicos de cádmio na germinação e desenvolvimento inicial de Schinus terebinthifolius}

\author{
Edevaldo da Silva1,*, M. Fátima S. Guilherme ${ }^{1}$, Habyhabanne M. Oliveira ${ }^{1}$, \\ Ladyanny N. C. P. Araújo ${ }^{1}$, Zenira C. V. Viana ${ }^{2}$ and Vera Lúcia C. S. Santos ${ }^{3}$ \\ 1 Universidade Federal de Campina Grande, Centro de Saúde e Tecnologia Rural, Unidade Acadêmica de Ciências Biológicas. Cx. Postal 61, 58708-110, Patos, Paraíba, Brazil \\ 2 Universidade Federal da Bahia, Instituto de Ciências da Saúde, Departamento de Biofunção. Av. Reitor Miguel Calmon s/n, Vale do Canela, 40110-100, Salvador, Bahia, Brazil \\ 3 Universidade Federal da Bahia, Instituto de Química, Departamento de Química Analítica. Rua Barão de Jeremoabo s/n, Ondina, 40170-115, Salvador, Bahia, Brazil \\ (*E-mail:edevaldos@yahoo.com.br) \\ http://dx.doi.org/10.19084/RCA16093
}

Received/recebido: 2016.07 .19

Received in revised form/recebido em versão revista: 2016.10 .29

Accepted/aceite: 2016.11 .23

\begin{abstract}
A B S T R A C T
Plants can absorb cadmium from contaminated soils. This toxic metal can cause many negative effects on plant's morphophysiological development. The aim of this study was to determine the biometric aspects and to assess the ecotoxicological effects of cadmium on the germination and initial development of pepper mastic (Schinus terebinthifolius). The experiment followed a completely randomized design with treatments consisting of eight cadmium concentrations $(0.0 ; 0.2 ; 0.4 ; 0.6 ; 0.8 ; 1.0 ; 2.0 ; 4.0$ and $6.0 \mathrm{mM})$, with four replications. The response variables analyzed included: percentage of germination speed index (GSI), length of shoots and roots of seedlings. Cadmium caused high percentage of inhibition on the germination of $S$. terebinthifolius, presenting negative effects from $0.2 \mathrm{mM}$ ( $35.2 \%$ inhibition) by $70.2 \%$ with $0.6 \mathrm{mM}$. In early seedling development, it was found that its presence interferes with the root growth more than with shoots. In both parts, cadmium interfered significantly from the concentration of 0.2 mM. However, the $0.4 \mathrm{mM}$ concentration impacts are more pronounced in the root system development. In environments contaminated by cadmium, establishing the germination and development of this species may not be possible.
\end{abstract}

Keywords: Schinus terebinthifolius Raddi, contamination, heavy metal.

\section{R E S U M O}

As plantas absorvem o cádmio de solos contaminados. Este metal tóxico pode causar efeitos negativos no desenvolvimento morfofisiológico da planta. O objetivo deste estudo consistiu em determinar os aspectos biométricos e avaliar os efeitos ecotoxicológicos do cádmio no desenvolvimento da aroeira-pimenta (Schinus terebinthifolius Raddi). O estudo, foi desenvolvido com oito tratamentos e quatro repetições em delineamento inteiramente casualizado, nas seguintes concentrações de cádmio: 0,0;0,2; 0,4; 0,6;0,8;1,0;2,0; 4,0 e 6,0 mM. As variáveis resposta foram a percentagem do índice de velocidade de germinação (IVG), o comprimento da parte aérea e da raiz das plântulas. O cádmio causou inibição na germinação de $S$. terebinthifolius a partir de $0,2 \mathrm{mM}$ (35,2\% de inibição), chegando a 70,2\% de inibição quando as sementes de $S$. terebinthifolius foram expostas a $0,6 \mathrm{mM}$. O cádmio também interferiu significativamente no crescimento da parte aérea e da raiz a partir da concentração de $0,2 \mathrm{mM}$. No entanto, a inibição do crescimento foi mais acentuada no sistema radicular. A sua presença pode afetar, principalmente, o sistema radicular. Assim, em ambientes contaminados por cádmio, a germinação e estabelecimento desta espécie podem não ser viáveis.

Palavras-chave: Schinus terebinthifolius Raddi, contaminação, metal pesado. 


\section{INTRODUCTION}

Environmental contamination caused by increasing concentrations of heavy metals has been one of the major environmental concerns (Bayramoglu and Arica, 2011). Anthropogenic activities such as mining, domestic effluents on farms (Järup and Åkesson, 2009), overuse of mineral fertilizers containing cadmium, sludge and wastewater (Tito et al.,2012) have increased the concentration of these pollutants in the soil, that can be absorbed by plants.

Risks of ecosystems contamination by these pollutantshaveworried duetotheir majorecologicalconsequences, being cadmium one of the heavy metals with greater phytotoxic potential (He et al., 2014).

Schinus terebinthifolius belongs to the Anacardiaceae family, is a tree widely found on Brazilian coast (Carvalho et al., 2013), in biomes caatinga, cerrado and rainforest. Besides being widely used as an herbal medicine (Carlini et al., 2013), it is used in reforestation programs and environmental recovery of degraded ciliary banks areas (Silva et al., 2012). Thus, due to its wide distribution, the species can be exposed to environments with soil contaminated by heavy metals such as cadmium.

Phytotoxicity of cadmium in cell tissues of plants causes negative effects on physiological and biochemical mechanisms, such changes being shown in the growth development (Sharma and Dietz, 2009). In the initial stages, this heavy metal may cause reduction in the percentage of seed germination (Ahmad etal., 2011; Kranner and Colville, 2011; Lamhamdi et al., 2011), in the germination rate index and the initial growth of seedlings (Sfaxi-Bousbih et al., 2010) and decreased leaf area, total chlorophyll content, carotenoid content, and the photochemical quantum yield of photosynthesis (Larsson et al., 1998).

This study aimed to assess the ecotoxicological effects of lead in the germinative development of pepper mastic (S. terebinthifolius).

\section{MATERIAL AND METHODS}

The experiment was conducted in the Environmental Sciences Laboratory of the Academic Unit of Biological Sciences of Federal University of Campina Grande - Paraiba). The seeds of S. terebinthifolius used in the research were acquired at the Instituto de Institute of Forestry Research and Studies (IPEF), Piracicaba, São Paulo. The viability assessment of the batch of seeds was analyzed through germination test, where 200 seeds were previously disinfected with sodium hypochlorite ( $\mathrm{NaClO} 2.5 \%$ ) for 10 minutes and sown in four Petri dishes $(4 \times 50$ seeds), with a double layer of paper sterilized (germitest) and moistened with $11 \mathrm{~mL}$ of distilled water (Brasil, 2009). To assess the effects of cadmium on seed germination and initial development of $S$. terebinthifolius eight experimental concentrations of cadmium (0.2, $0.4,0.6,0.8,1.0,2.0,4.0$ and $6.0 \mathrm{mM}$ ) were used, besides the control. The seeds were disinfected (2.5\% NaClO for 10 minutes) and then immersed for 30 minutes in $20 \mathrm{~mL}$ of their respective experimental concentrations. Cadmium solutions were prepared from cadmium nitrate $\left(\mathrm{Cd}\left(\mathrm{NO}_{3}\right)_{2}\right)$ in $\mathrm{pH}$ 6.0, while distiller water was used as control. Seeds were sown in Petri dishes (150 mm diameter) with double layer paper (germitest) soaked in cadmium solution in different concentrations and water. The experiment was carried out in quadruplicates with 30 seeds per replicate. Seeds were kept at temperature of $30^{\circ} \mathrm{C} \pm 2$ and photoperiod of 16 hours light and 8 hours dark, during 20 days.

The response variables to assess effects of cadmium were: the percentage of germination; the germination speed index (GSI), both quantified according to Maguire (1962), and the daily growth of shoot and root of seedlings using a digital caliper $(0.01 \mathrm{~mm})$. The experimental data were collected during 20 days from the day of sowing.

Statistical analyzes of the results of measurements were performed using the statistical software SPSS 20.0. When necessary, the data were converted into arc $\operatorname{sen}[(x+0,5) / 100]^{0.5}$ to ensure data homoscedasticity, being assessed through analysis of variance (ANOVA) followed by Tukey's test $(P<0.05)$ to determine statistical significance of difference among the variances. Additionally, the regression analysis was used to assess the relation between the variation in growth of the seedling parts and the used cadmium concentration. For all statistical analyzes, the significance level of $P<0.05$ was considered. 


\section{RESULTS AND DISCUSSION}

The germination and seedling growth, generally was negatively and significantly influenced by the different concentrations of cadmium. The concentrations of 0.2 and $0.4 \mathrm{mM}$ of cadmium caused statistically similar inhibitions, with the average percentage of $35.2 \%$ lower of germination compared to control germination (Figure 1). Similar trend of decreasing values was also observed for the germination speed index (Figure 2).

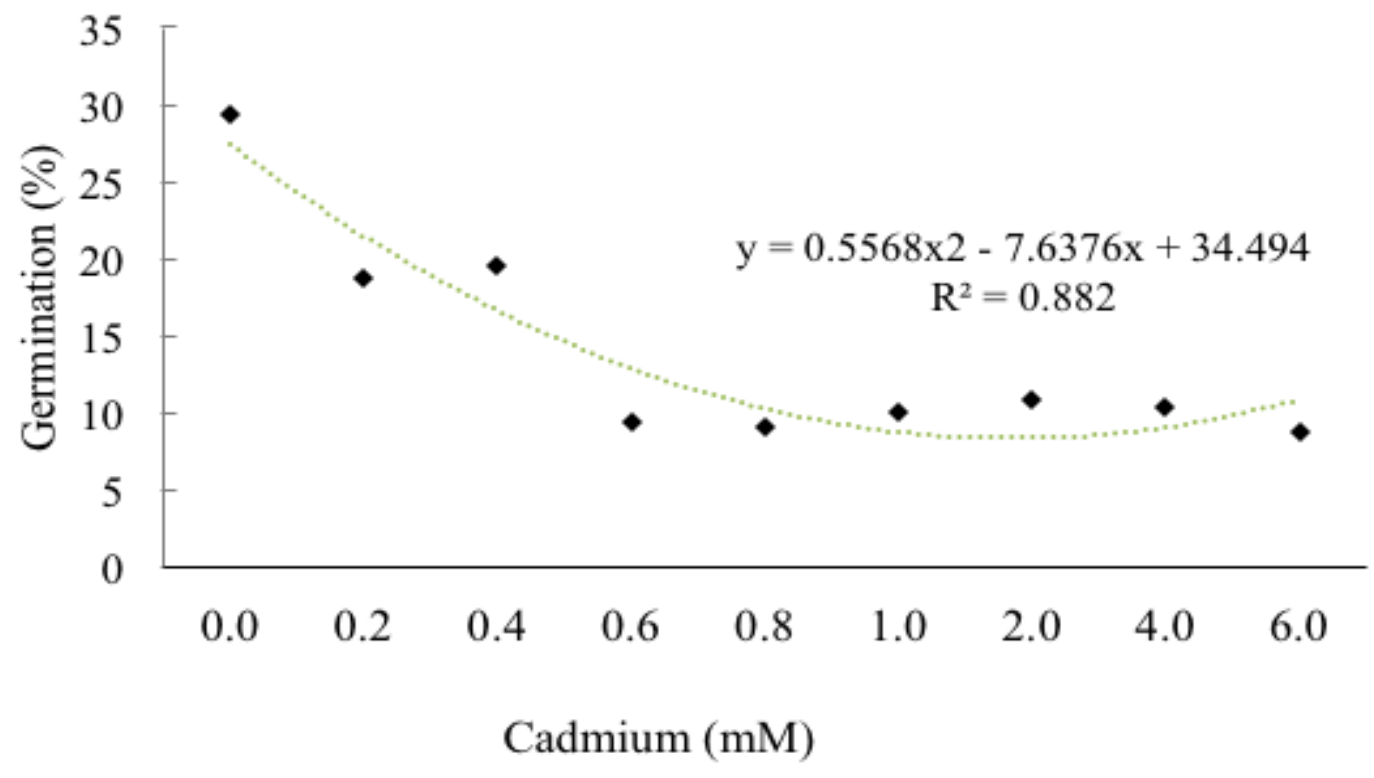

Figure 1-Germination (\%) of Schinus terebinthifolius Raddi seeds submitted to different cadmium concentrations. Mean of $\mathrm{n}=200$ seeds, $P<0.05$.

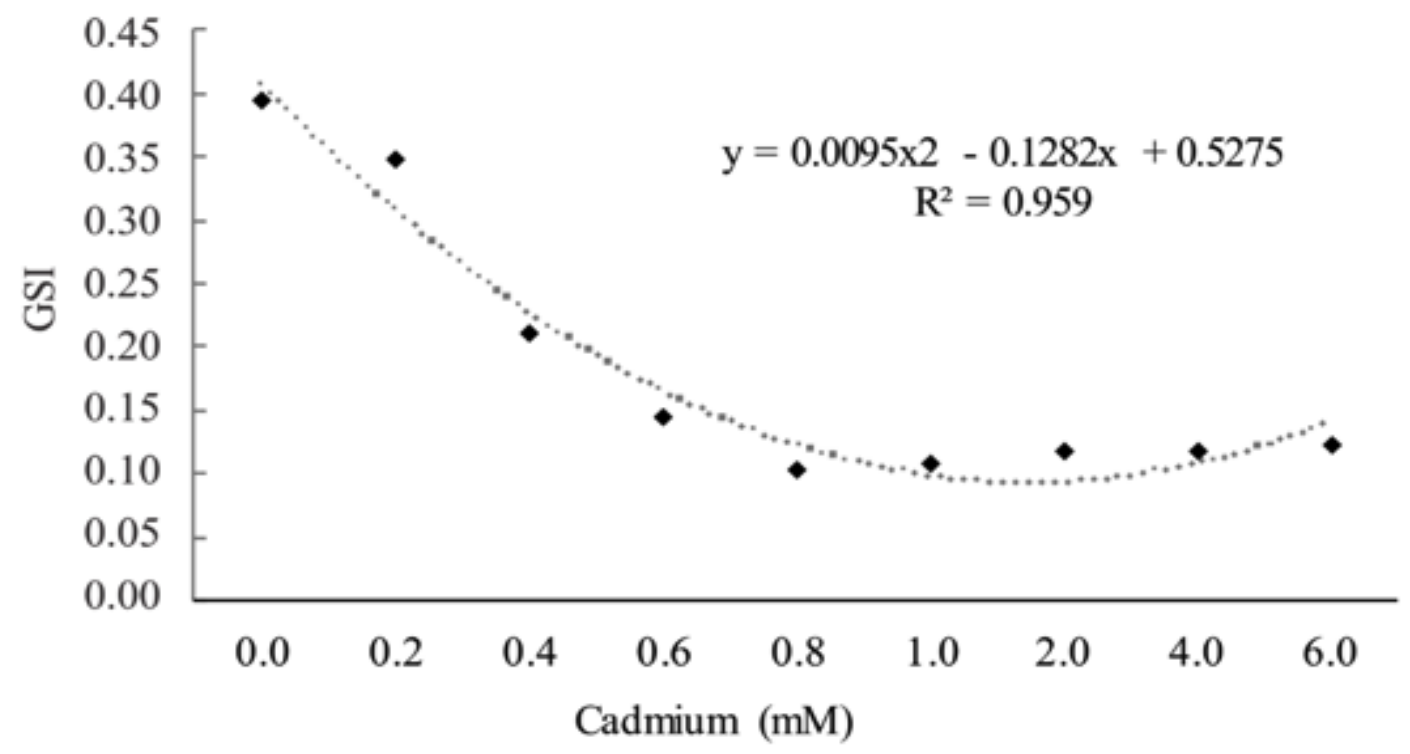

Figure 2 - Germination speed index (GSI) of Schinus terebinthifolius Raddi seeds submitted to different cadmium concentrations. Mean of $\mathrm{n}=200$ seeds, $P<0.05$. 
Concentrations from $0.6 \mathrm{mM}$ compromised more than half of the germination potential of the seeds. However, higher concentrations of cadmium (up to $6.0 \mathrm{mM}$ ) caused no greater inhibitory effect than that observed at $0.6 \mathrm{mM}$ (Figure 3).

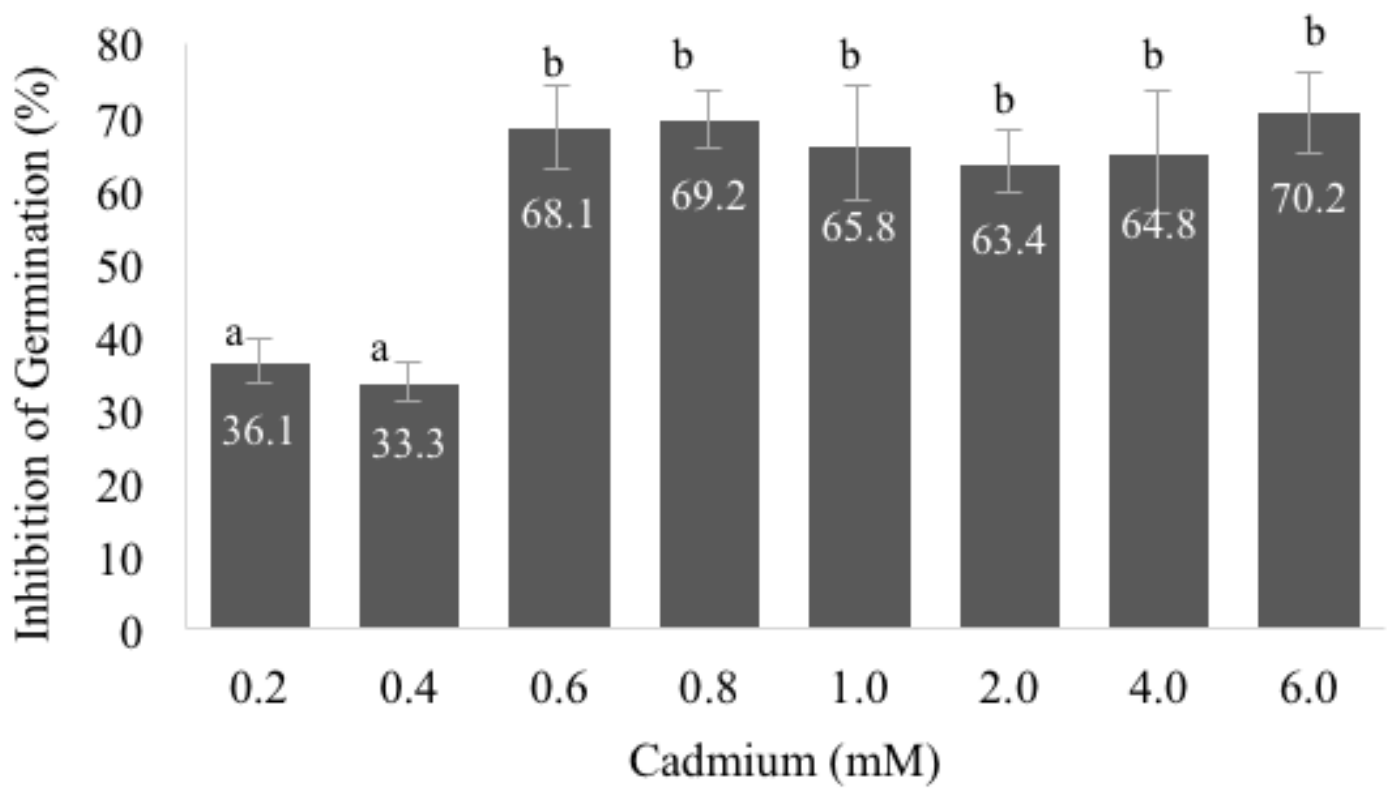

Figure 3 - Germination inhibition (\%) of Schinus terebinthifolius Raddi seeds in the presence of several cadmium concentrations. Percentage with the same letter are not statistically different from each other $(P<0.05)$. Error bars represent SD of the mean expressed in percentage, $\mathrm{n}=120$ seeds, $P<0.05$.

Cadmium showed very high potential for inhibition of root growth of pepper mastic, where the seedlings that have been developed exposed to greater concentrations, 4.0 and $6.0 \mathrm{mM}$. This high inhibitory effect was also observed in the shoot. However, the shoot was more tolerant to the presence of cadmium than the root (Table 1).

The regression analysis between cadmium concentrations and growth of shoot and root reported values of significant correlations, with coefficient of determination equal to 0.90 to shoot and 0.85 to root (Figure 4). This indicates that the reduced growth of both meristems of the seedling was probably due to the toxic effect of increasing concentrations of cadmium. It was observed that concentrations of $0.2 \mathrm{mM}$ of cadmium have already significantly affected the growth of shoot and root (Table 1). However, at this concentration, the percentage of inhibition of the root was higher than that observed in shoots, revealing that the roots are more sensitive to the presence of cadmium.

Table 1 - Potential(\%)ofinhibition ontherootand shootgrowth of of Schinus terebinthifolius Raddi after 10 days of treatment with different cadmium concentrations

\begin{tabular}{crc}
\hline Concentration $(\mathbf{m M})$ & Root & Shoot \\
\hline 0.2 & $64.3 \mathrm{e}$ & $12.7 \mathrm{e}$ \\
0.4 & $222.0 \mathrm{~d}$ & $14.8 \mathrm{~d}$ \\
0.6 & $234.6 \mathrm{~d}$ & $13.1 \mathrm{e}$ \\
0.8 & $215.0 \mathrm{~d}$ & $13.2 \mathrm{e}$ \\
1.0 & $245.0 \mathrm{~d}$ & $23.2 \mathrm{c}$ \\
2.0 & $297.0 \mathrm{c}$ & $46.3 \mathrm{~b}$ \\
4.0 & $789.0 \mathrm{a}$ & $301.8 \mathrm{a}$ \\
6.0 & $674.9 \mathrm{~b}$ & $304.9 \mathrm{a}$ \\
\hline
\end{tabular}

Values with the same letter, in the same column, are not statistically different from each other $(P<0.05)$. 


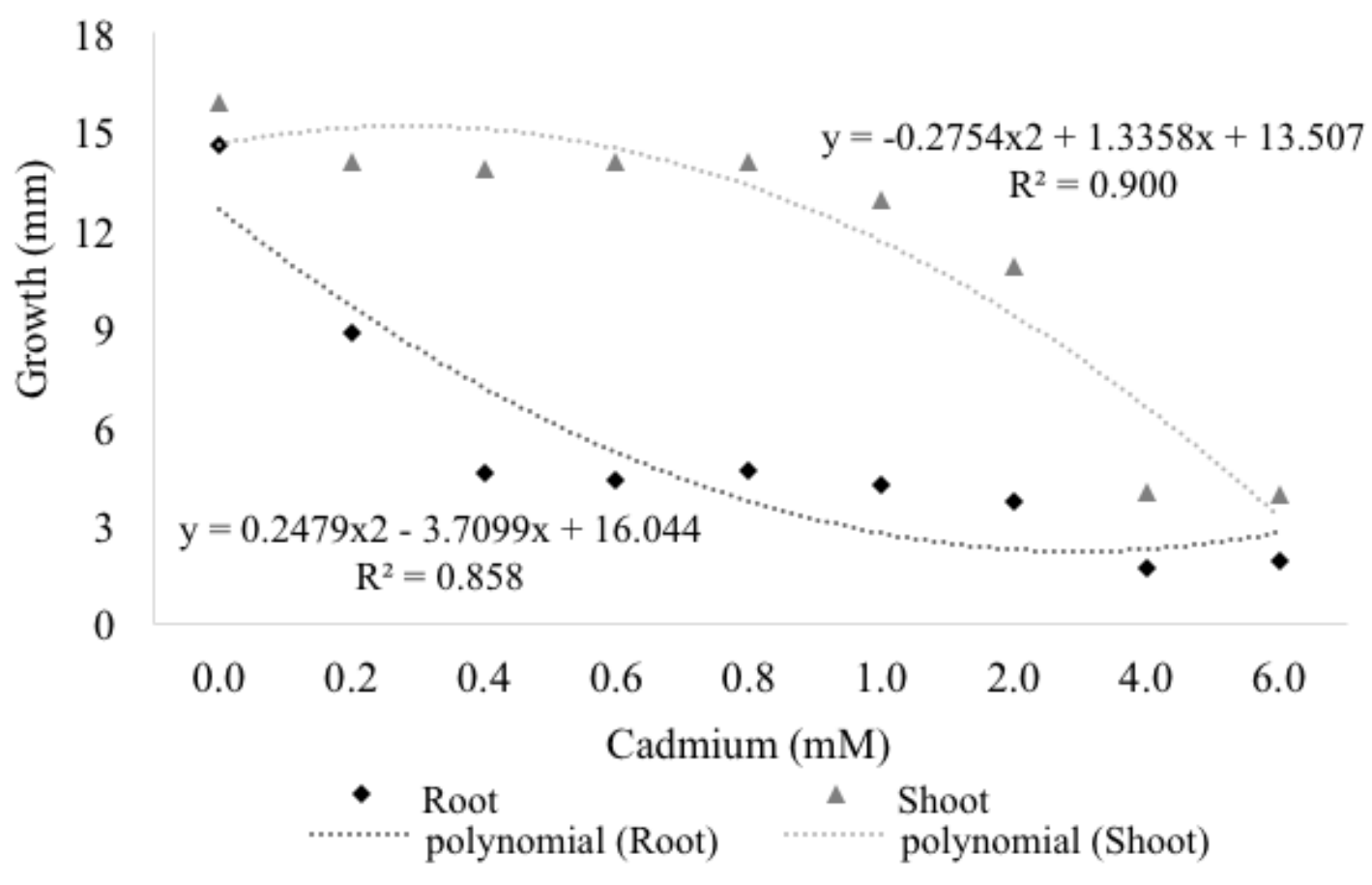

Figure 4 - Root and shoot growth of Schinus terebinthifolius Raddi after 10 days of treatment with different cadmium concentrations.

Kranner \& Colville (2011) reported that cadmium has the potential to inhibit the germination and growth of seedlings. Similar trend of inhibition was found in the results of this work.

The mechanism of toxicity of heavy metals in plants involves a complex network of soil mobilization and root absorption and transport, capture and distribution in the intracellular space of the plant (Clemens et al., 2002). Their accumulation in plant cell can have effects on biochemical and molecular levels, causing damage to biomolecules and causing oxidative stress with consequent effects on plant development (Hossain et al., 2011), such as the inhibition of germination and growth (Souza et al., 2011).

The reduction in the growth of the shoot and, especially, the root may threaten the establishment and the emergence of this species in habitats with toxic levels of cadmium in the soil. Thus, future generations of S. terebinthifolius inserted as seedling in degraded environments would have difficulty regarding the germination and development of its seeds in this environment.
The literature has not reported research on the ecotoxicology of toxic metals in the development of forest species. However, there are studies that report negative effects of the presence of cadmium during germination and initial development of several other plant groups (Wunder et al., 2009; Lin et al., 2014).

On Table 2, it was also observed that the plants suffer toxic effects of cadmium at different concentrations, ranging from $0.05 \mathrm{mg} \mathrm{L}^{-1}$ (S. molesta) to $12.5 \mathrm{mg} \mathrm{L}^{-1}$ (R. diphyllum).

These studies report tolerance variations among plant species on the presence of this metal. This is because the plant influences the absorption and translocation of metals to their interior, being it possible that different plant species that grow in the same soil present different absorption for a given element (Nordløkken et al., 2015).

Wunder et al. (2009) observed that the germination of $R$. diphyllum megaspores in the presence of cadmium at the concentration of $50 \mathrm{mg} \mathrm{L}^{-1}$ reduced in more than $58 \%$ the germination and the 
Table 2 - Cadmium concentrations that caused toxic effects in the development of shoots and roots of several plant species reported in the literature and in this research

\begin{tabular}{|c|c|c|c|c|}
\hline Species & Shoot (PA) & Root (R) & Inhibition & Reference \\
\hline Eichhornia crassipes (Mart.) Solms & $1.47 \mathrm{mg} \mathrm{L}^{-1}$ & $0.64 \mathrm{mg} \mathrm{L}^{-1}$ & \multirow{2}{*}{$25 \%$} & \\
\hline Salvinia auriculata Aublet & $0.10 \mathrm{mg} \mathrm{L}^{-1}$ & $0.06 \mathrm{mg} \mathrm{L}^{-1}$ & & Oliveira et al. (2001) \\
\hline Salvinia molesta Mitchell & $0.05 \mathrm{mg} \mathrm{L}^{-1}$ & - & - & Gupta \& Devi (1992) \\
\hline Regnellidium diphyllum Lindm. & $12.5 \mathrm{mg} \mathrm{L}^{-1}$ & $12.5 \mathrm{mg} \mathrm{L}^{-1}$ & - & Wunder et al. (2009) \\
\hline Sinapis alba $\mathrm{L}$. & - & $3.60 \mathrm{mg} \mathrm{L}^{-1}$ & $50 \%$ & Fargasová (2001) \\
\hline Galinsoga parviflora Cav. & - & 50 mg kg-1 & $20 \%$ & Lin et al. (2014) \\
\hline \multirow{2}{*}{ Suaeda salsa L. } & \multirow{2}{*}{$0.1 \mathrm{mg} \mathrm{L-1}$} & \multirow{2}{*}{$0.1 \mathrm{mg} \mathrm{L}^{-1}$} & $38 \% *(\mathrm{R})$ & \multirow{2}{*}{ Liu et al. (2012) } \\
\hline & & & $27 \%^{*}(\mathrm{PA})$ & \\
\hline \multirow{2}{*}{ Schinus terebinthifolius Raddi } & \multirow{2}{*}{$41.4 \mathrm{mg} \mathrm{L}^{-1}$} & \multirow{2}{*}{$46.3 \mathrm{mg} \mathrm{L}^{-1}$} & $36 \%(\mathrm{PA})$ & \multirow{2}{*}{ Silva et al. (2014) } \\
\hline & & & $46 \%(\mathrm{R})$ & \\
\hline
\end{tabular}

* Approximate values.

concentration of $100 \mathrm{mg} \mathrm{L}^{-1}$ completely inhibited germination. This species reported lower tolerance to cadmium than $S$. terebinthifolius; where in similar concentrations of cadmium $(0.2 \mathrm{mM}$, equivalent to $41.4 \mathrm{mg} \mathrm{L}^{-1}$ ) showed inhibition of $36.1 \%$ in seed germination. The high intolerance of $S$. molesta is possibly for being an aquatic species and its roots are exposed directly to the contaminated water. S. terebinthifolius is also used in reforestation of wetlands, and can also be exposed to pollution by heavy metal transported by water. Despite the variability in tolerance to cadmium, all research report that the toxic effects of cadmium are higher in the roots when compared to its effects in the shoot. The same trend was observed in this study. The roots are the main absorption organ of the plants and, usually, the highest concentrations of heavy metals are found in them. Cadmium is retained and immobilized on the cell wall (He et al., 2009) by means of connections with negative charges of the cell walls and then it is transferred to the shoot (Grant et al., 1998). Plants subjected to exposure of toxic levels of cadmium for long periods generally causes great interference with their growth due to decreased synthesis of compounds rich in thiol group, which could, by complexation, prevent the action of the metal (Ding et al., 1994).

\section{CONCLUSIONS}

The cadmium present at low concentrations (from $0.2 \mathrm{mM}$ ) causes high percentage of inhibition in germination and development of shoots and roots of S. terebinthifolius. It is intolerant to cadmium at low concentrations, affecting mainly the root system. In environments contaminated by cadmium, establishing the germination and development of this species may not be possible.

\section{ACKNOWLEDGEMENTS}

The authors would like to thank the National Council for Scientific and Technological Development $(\mathrm{CNPq})$ for the financial support.

\section{REFERENCES}

Ahmad, P.; Nabi, G. \& Ashraf, M. (2011) - Cadmium-induced oxidative damage in mustard [Brassica juncea (L.) Czern. \& Coss.] plants can be alleviated by salicylic acid. South African Journal of Botany, vol. 77, n. 1, p. 36-44. http://dx.doi.org/10.1016/j.sajb.2010.05.003

Bayramoglu, G. \& Arica, M.Y. (2011) - Preparation of a composite biosorbent using Scenedesmus quadricauda biomass and alginate/polyvinyl alcohol for removal of $\mathrm{Cu}$ (II) and $\mathrm{Cd}$ (II) ions: isotherms, kinetics, and thermodynamic studies. Water, Air, \& Soil Pollution, vol. 221, n. 1, p. 391-403. http://dx.doi.org/10.1007/ s11270-011-0798-5 
Brasil (2009) - Regras para análise de sementes. Ministério da Agricultura, Pecuária e Abastecimento, Brasília http://www.agricultura.gov.br/arq editor/file/Laborat\%C3\%B3rio/Sementes/Regras\%20para\%20Analise\%20de\%20Sementes.pdf

Carlini, E.A.; Duarte-Almeida, J.M. \& Tabach, R. (2013) - Assessment of the Toxicity of the Brazilian Pepper Trees Schinus terebinthifolius Raddi (Aroeira-da-praia) and Myracrodruon urundeuva Allemão (Aroeira-do-sertão). Phytotherapy Research, vol. 27, n. 5, p. 692-698. http://dx.doi.org/10.1002/ptr.4767

Carvalho, M.G.; Melo, A.G.N.; Aragão, C.F.S.; Raffin, F.N. \& Moura T.F.A.L. (2013) - Schinus terebinthifolius Raddi: chemical composition, biological properties and toxicity. Revista Brasileira de Plantas Medicinais, vol. 15, n. 1, p. 158-169. http://dx.doi.org/10.1590/S1516-05722013000100022

Clemens, S.; Palmgren, M.G. \& Krämer, U. (2002) - A long way ahead: understanding and engineering plant metal accumulation. Trends in Plant Science, vol. 7, n. 7, p. 309-315. http://dx.doi.org/10.1016/S1360-1385(02)02295-1

Ding, X.; Jiang, J.; Wang, Y.; Wang, W. \& Ru, B. (1994) - Bioconcentration of cadmium in water hyacinth (Eichhornia crassipes) in relation to thiol group content. Environmental Pollution, vol. 84, n. 1, p. 93-96. http:// dx.doi.org/10.1016/0269-7491(94)90075-2

Fargašová, A. (2001) - Phytotoxic effects of Cd, Zn, Pb, Cu and Fe on Sinapis alba L. seedlings and their accumulation in roots and shoots. Biologia Plantarum, vol. 44, n. 3, p. 471-473. http://dx.doi.org/10.1023/A:1012456507827

Grant, C.A.; Buckley, W.T.; Bailey, L.D. \& Selles, F. (1998) - Cadmium accumulation in crops. Canadian Journal of Plant Science, vol. 78, n. 1, p. 1-17. http://dx.doi.org/10.4141/P96-100

Gupta, M. \& Devi, S. (1992) - Cadmium sensitivity inducing structural responses in Salvinia molesta Mitchell. Bulletin of Environmental Contamination and Toxicology, vol. 49, n. 3, p. 436-443.

He, J.; Ren, Y.; Chen, X. \& Chen, H. (2014) - Protective roles of nitric oxide on seed germination and seedling growth of rice (Oryza sativa L.) under cadmium stress. Ecotoxicology and Environmental Safety, vol. 108, p. 114-119. http://dx.doi.org/10.1016/j.ecoenv.2014.05.02

He, J.Y.; Ren, Y.F.; Wang, F.J.; Pan, X.B.; Zhu, C. \& Jiang, D.A. (2009) - Characterization of cadmium uptake and translocation in a cadmium-sensitive mutant of rice (Oryza sativa L. ssp. japonica). Archives of Environmental Contamination and Toxicology, vol. 57, n. 2, p. 299-306. http://dx.doi.org/10.1007/s00244-008-9273-8

Hossain, M.A.; Piyatida, P.; Silva, J.A.T. \& Fujita, M. (2012) - Molecular mechanism of heavy metal toxicity and tolerance in plants: central role of glutathione in detoxification of reactive oxygen species and methylglyoxal and in heavy metal chelation. Journal of Botany, vol. 2012, art. 872875. http://dx.doi.org/10.1155/2012/872875

Järup, L. and Åkesson, A. (2009) - Current status of cadmium as an environmental health problem. Toxicology and Applied Pharmacology, vol. 238, n. 3, p. 201-208. http://dx.doi.org/10.1016/j.taap.2009.04.020

Kranner, I. \& Colville, L. (2011) - Metals and seeds: biochemical and molecular implications and their significance for seed germination. Environmental and Experimental Botany, vol. 72, n. 1, p. 93-105. http://dx.doi. org/10.1016/j.envexpbot.2010.05.005

Lamhamdi, M.; Bakrim, A.; Aarab, A.; Lafont, R. \& Sayah, F. (2011) - Lead phytotoxicity on wheat (Triticum aestivum L.) seed germination and seedlings growth. Comptes Rendus Biologies, vol. 334, n. 2, p. 118-126. http://dx.doi.org/10.1016/j.crvi.2010.12.006

Larsson, E.H.; Bornman, J.F. \& Asp, H. (1998) - Influence of UV-B radiation and Cd ${ }^{2+}$ on chlorophyll fluorescence, growth and nutrient content in Brassica napus. Journal of Experimental Botany, vol. 49, n. 323, p. 1031-1039. http://dx.doi.org/10.1093/jxb/49.323.1031

Lin, L.; Jin, Q.; Liu, Y.; Ning, B.; Liao, M.A. \& Luo, L. (2014) - Screening of a new cadmium hyperaccumulator, Galinsoga parviflora, from winter farmland weeds using the artificially high soil cadmium concentration method. Environmental Toxicology and Chemistry, vol. 33, p. 2422-2428. http://dx.doi.org/10.1002/etc.2694

Liu, S.; Yang, C.; Xie, W.; Xia, C. \& Fan, P. (2012) - The effects of cadmium on germination and seedling growth of Suaeda salsa. Procedia Environmental Sciences, vol. 16, p. 293-298. http://dx.doi.org/10.1016/j.proenv.2012.10.041

Maguire, J. (1962) - Speed of germination aid in selection and evaluation for seedling and vigour. Crop Science, vol. 2, n. 2, p. 176-177.

Nordløkken, M.; Berg, T.; Flaten, T.P. \& Steinnes, E. (2015) - Essential and non-essential elements in natural vegetation in southern Norway: Contribution from different sources. Science of the Total Environment, vol. 502, p. 391-399. http://dx.doi.org/10.1016/j.scitotenv.2014.09.03

Oliveira, J.A.; Cambraia, J.; Oliva, M.A. \& Jordão, C.E.C.P. (2001) - Absorção e acúmulo de cádmio e seus efeitos sobre o crescimento relativo de plantas de agua pé e de salvínia. Revista Brasileira de Fisiologia Vegetal, vol. 13, n. 3, p. 329-341. http://dx.doi.org/10.1590/50103-31312001000300008 
Sfaxi-Bousbih, A.; Chaoui, A. \& El Ferjani, E. (2010) - Cadmium impairs mineral and carbohydrate mobilization during the germination of bean seeds. Ecotoxicology and Environmental Safety, vol. 73, n. 6, p. 1123-1129. http://dx.doi.org/10.1016/j.ecoenv.2010.01.005

Sharma, S.S. \& Dietz, K. (2006) - The significance of amino acids and amino acid derived molecules in plant responses and adaptation to heavy metal stress. Journal of Experimental Botany, vol. 57, n. 4, p. 711-726. http://dx.doi.org/10.1093/jxb/erij073

Silva, A.M.; Canuto, D.S.O. \& Moraes, M.L.T. (2012) - Avaliação das propriedades químicas em solo de cerrado sob reflorestamento ciliar. Floresta, vol. 42, n. 1, p. 49-58. http://dx.doi.org/10.5380/rf.v42i1.26295

Souza, L.A.; Andrade, S.A.L.; Souza, S.C.R. \& Schiavinato, M.A. (2011) - Tolerância e potencial fitorremediador de Stizolobium aterrimum associada ao fungo micorrízico arbuscular Glomus etunicatum em solo contaminado por chumbo. Revista Brasileira de Ciência do Solo, vol. 35, n. 4, p. 1441-1451. http://dx.doi. org/10.1590/S0100-06832011000400038

Tito, G.A.; Chaves, L.H.G. \& Guerra, H.O.C. (2012) - Mobilidade do zinco e do cobre em Argissolo com aplicação de argila bentonita. Revista Brasileira de Engenharia Agrícola e Ambiental, vol. 16, n. 9, p. 938-945. http://dx.doi.org/10.1590/S1415-43662012000900003

Wunder, D.A.; Droste, A. \& Windish, P.G. (2009) - Megaspore germination and initial development of Regnellidium diphyllum Lindman (Pteridophyta, Marsileaceae) sporophytes in the presence of cadmium. Brazilian Journal of Botany, vol. 32, n. 1, p. 177-181. http://dx.doi.org/10.1590/\$0100-84042009000100017 